\title{
TEMAS EM EDUCAÇÃO ESPECIAL: MÚLTIPLOS OLHARES
}

\author{
Fabiana Sayuri SAMESHIMA
}

ALMEIDA, Maria Amélia; MENDES, Enicéia Gonçalves; HAYASHI, Maria Cristina Piumbato Innocentini (Org.). Temas em Educação Especial: múltiplos olhares. Araraquara: Junqueira \&Marin; Brasília: CAPES-PROESP, 2008.

O livro Temas em Educação Especial: múltiplos ol hares é uma obra que reúne os diversos olhares sobre a Educação Especial, do ponto de vista de vários profissionais que atuam na área. Seu conteúdo permite reflexões significativas, além de contribuir para a produção do conhecimento.

É uma publicação resultante dos trabalhos apresentados no II Congresso Brasileiro de Educação Especial e contemplam temáticas variadas distribuídas em 9 partes.

A inclusão é o foco principal da primeira parte da obra. Destacam-se os trabal hos de revisão teórica, políticas públicas e a importância dos estudos de formação continuada e ensino colaborativo voltados às questões da inclusão escolar.

$\mathrm{N}$ a segunda parte do livro, os pesquisadores discorrem sobre as representações sociais e formação docente. Os trabal hos salientam o processo de formação inicial de docentes com vistas à inclusão de alunos com necessidades especiais, e as expectativas e percepções de estagiários e professores diante sua inserção no ambiente escolar do aluno deficiente.

Os al unos com necessidades especiais no ensino superior compõem a tercei ra parte deste livro. N este capítulo são discutidas questões que enfatizam o acesso e a permanência do aluno nas salas de aulas, além de apresentar trabalhos que se preocupam com a preparação docente e a necessidade das instituições de ensino superior desenvolverem políticas quefavoreçam a formação de professores para atender esse alunado.

Na quarta parte do livro são abordadas as questões do aborto por anomalias fetais, recém-nascidos de risco e pré-escolares agressivos. Esta parte contempla ações de mobilização em torno do aborto e as manifestações da

\footnotetext{
${ }^{1}$ Doutoranda do Programa de Pós-Graduação em Educação da Unesp - campus de Marília fabianasameshima@yahoo.com.br
} 
comunidade brasileira de deficientes pela defesa de seus interesses. Encontramsetambém pesquisas que envolvem técnicas para suprir as dificuldades existentes no atendimento do recém-nascido de risco, incentivando suas potencialidades para facilitar seu desenvolvimento global.

Estão agrupadas na quinta parte desta obra, temáticas variadas sobre os familiares de crianças com necessidades especiais. De um modo geral, os trabal hos que compõem este capítulo, investigam os recursos, técnicas, programas que permitam estabel ecer critérios de organização, na el aboração das orientações às famílias sobre o desenvolvimento da linguagem, e da melhora do desempenho acadêmico das crianças no âmbito escolar.

As contribuições do campo das habilidades sociais para a Educação especial, perfazem a sexta parte deste livro. É uma área que vem se consolidando tanto na pesquisa quanto na prática e visa a maximização de comportamentos socialmente habilidosos e competentes. Os estudos descritos comprovam que o crescimento dessa área abrange diferentes contextos inclusive o da Educação especial.

A sétima parte da obra é composta por dois estudos que investigam o atendimento a alunos com altas habilidades. O conteúdo desta parte aborda questões políticas de atendimento educacional para estes alunos, as práticas para a inclusão, suas novas abordagens, bem como, a motivação do professor e de toda a comunidade escolar para favorecer o sucesso dos programas de atendimento.

$\mathrm{N}$ a oitava parte são descritos dois estudos sobre os aspectos comunicativos do autismo. A mbos identificam as formas de comunicação de crianças com transtornos do espectro autístico, sendo uma com foco nas situações de atividade de vida diária e outra durante a interação lúdica entre mães e filhos.

Por fim, na última parte do livro, são discutidas temáticas variadas como a caracterização de recursos de tecnologia assistiva para indivíduos com deficiência; aspectos relacionados à prática do terapeuta ocupacional no campo da Educação especial; escolarização e contribuições da Iniciação científica na formação de cientistas para a Educação especial.

Esta obra éum norteador para estudantes, professores e pesquisadores em formação, que buscam o conhecimento de métodos, técnicas, recursos, materiais que possam ser desenvolvidos na área da Educação especial. 